\title{
25. COPPER MINERALIZATION AT SITE 884 IN THE NORTH PACIFIC ${ }^{1}$
}

\author{
Gerald R. Dickens, ${ }^{2}$ Robert M. Owen, ${ }^{2}$ and Thomas F. Pedersen ${ }^{3}$
}

\begin{abstract}
Occasional grains and veinlets of native copper associated with blue-green stringers and haloes were observed (on ship) in certain intervals of claystone recovered at Ocean Drilling Program Site 884 (Detroit Seamount). Similar deep-sea, sediment-hosted copper mineralization previously has been documented at five Deep Sea Drilling Project sites in the Atlantic and Pacific oceans, but limited descriptions concerning these occurrences generally precludes understanding their origin. Electron microscopic and $\mathrm{X}$-ray diffraction analyses were performed on copper-mineralized samples (both sieved bulk sediment and in situ sediment slices) to describe more completely the copper mineralization at Site 884 . These analyses demonstrate that individual grains of "native copper" are often better described as native copper and/or cuprite occurring within and adjacent to partially dissolved remains of carbonate tests (often foraminifers). The blue-green haloes and stringers are composed of hydrous copper chloride (atacamite). White calcium carbonate rhombs often surround the copper mineralization; moreover, copper mineralization typically is found along fracture surfaces (e.g., microfaults and/or slickenslides). These results suggest a diplogenetic depositional mechanism that involves migrating (ascending?) chlorine-rich, low-temperature, slightly acidic, and copper-bearing fluids that precipitate native copper (and possibly cuprite) upon changes in Eh-pH within previously deposited and fractured sediment. The atacamite and carbonate rhombs are secondary and represent either late-stage precipitation from a modified copper-chloride fluid or, alternatively, alteration of precursor native copper (and/or other copper phases). This basic depositional mechanism is somewhat analogous to models proposed for emplacement of terrestrial "red-bed" copper ores; whether the model can explain previously reported DSDP occurrences of sediment-hosted native copper remains an open question and requires reexamination of these occurrences. We note, however, several similarities exist between copper mineralization at Site 884 and that at the DSDP sites.
\end{abstract}

\section{INTRODUCTION}

An intriguing and recurring phenomenon found in deep-sea sediment is the presence of native copper. Although geochemical considerations (e.g., $\mathrm{Cu}$ concentrations and Eh within sediment and surrounding pore waters) suggest that pelagic sediment is an unlikely depositional regime, native copper that obviously was deposited in situ has been reported in deep-sea sediment at several DSDP sites (Zemmels et al., 1972; Donnelly and Nalli, 1973; Jenkyns, 1976; Siesser, 1978; Knox, 1985). Three basic depositional models have been suggested for these occurrences (Jenkyns, 1976; Siesser, 1978; Knox, 1985): (1) current-transported, copper-bearing solutions derived from undersea volcanogenic exhalations precipitated copper phases onto the seafloor (syngenetic); (2) copper-rich pore waters derived from decomposition of organic matter or microorganisms reprecipitated native copper upon changes in sediment Eh-pH (early diagenetic); and (3) ascending copper-bearing fluids derived from underlying basalt precipitated native copper upon changes in sediment Eh-pH (diplogenetic). General acceptance of any of these models has been precluded because of a paucity of supporting evidence.

These occurrences of deep-sea native copper may be relevant to the study of mineral deposits because the aforementioned depositional models also have been invoked to explain ore-grade sedimenthosted copper deposits on land (e.g., Brown, 1981; Kirkham, 1989). However, before comparisons between terrestrial and pelagic sediment-hosted copper deposition can be explored, more thorough descriptions of deep-sea copper mineralization are needed. In particular, there is a lack of information concerning (1) additional minerals that may have been deposited in association with native copper; (2) potential relations between sedimentary structures (e.g., microfaults) and copper mineralization; and (3) textural relations between native cop-

\footnotetext{
${ }^{1}$ Rea, D.K., Basov, I.A., Scholl, D.W., and Allan, J.F. (Eds.), 1995. Proc. ODP, Sci Results, 145: College Station, TX (Ocean Drilling Program).

${ }^{2}$ Department of Geological Sciences, University of Michigan, 1006 C.C. Little Building, Ann Arbor, MI 48109-1063, U.S.A

${ }^{3}$ Department of Oceanography, University of British Columbia, 6270 University Boulevard, Vancouver, British Columbia V6T IZ4, Canada.
}

per and surrounding sediment. The occurrence of native copper observed within sediment at Site 884 , therefore, provides an opportunity to augment our existing knowledge of copper mineralization in pelagic sediment. Here, we present results of various analyses regarding copper mineralization at Site 884, with particular emphasis on information generally missing in previous notes on deep-sea, sedimenthosted native copper.

\section{COPPER MINERALIZATION AT SITE 884 (SHIPBOARD DESCRIPTION)}

Site 884 is located in the western North Pacific at a water depth of $3836 \mathrm{~m}$ on the flank of the Detroit Seamount (Rea, Basov, Janecek, Palmer-Julson, et al., 1993; Fig. 1). Drilling at this site recovered approximately $854 \mathrm{~m}$ of sediment and $87 \mathrm{~m}$ of basalt, which subsequently was divided into three units on the basis of lithology (Rea, Basov, Janecek, Palmer-Julson, et al., 1993; Fig. 1): Unit I (between 0 and $604.8 \mathrm{mbsf}$ ) is composed of variable proportions of diatoms and clay; Unit II (between 604.8 and 854 mbsf) consists of chalk, conglomerate, and clay; and Unit III (greater than $854 \mathrm{mbsf}$ ) is basalt.

Copper mineralization was described (aboard ship) within four intervals of the recovered sequence at Site 884 (Rea, Basov, Janecek, Palmer-Julson, et al., 1993; Fig. 1). Although individual occurrences within each interval typically are $<1 \mathrm{~mm}$ across, they are observed easily because their color contrasts markedly with the surrounding lithology. Copper-colored veinlets and blebs were found on a single fracture surface in Unit III basalt (Hole 884E). Approximately $45 \mathrm{~m}$ above the basalt, disseminated copper-colored grains and veinlets were described in lower Eocene, ashy, blue-gray claystone in the core catcher of Sample 145-884B-86X-CC ( 806 mbsf). Bluish green mottles surrounding apparent native copper grains were found higher in the sedimentary column (613-627 mbsf; $\sim 240 \mathrm{~m}$ above basalt) in lower Miocene gray claystone in Cores $145-884 \mathrm{~B}-67 \mathrm{X}$ and $-68 \mathrm{X}$. Bluish green haloes and stringers surrounding copper-colored veinlets, grains, and twinned crystals also were found in middle Miocene gray claystone in Cores 145-884B-57X and -58X (515-521 mbsf; $\sim 335 \mathrm{~m}$ above basalt). Most copper mineralization appeared to exist along microfaults and/or slickenslides in the latter three intervals. It 


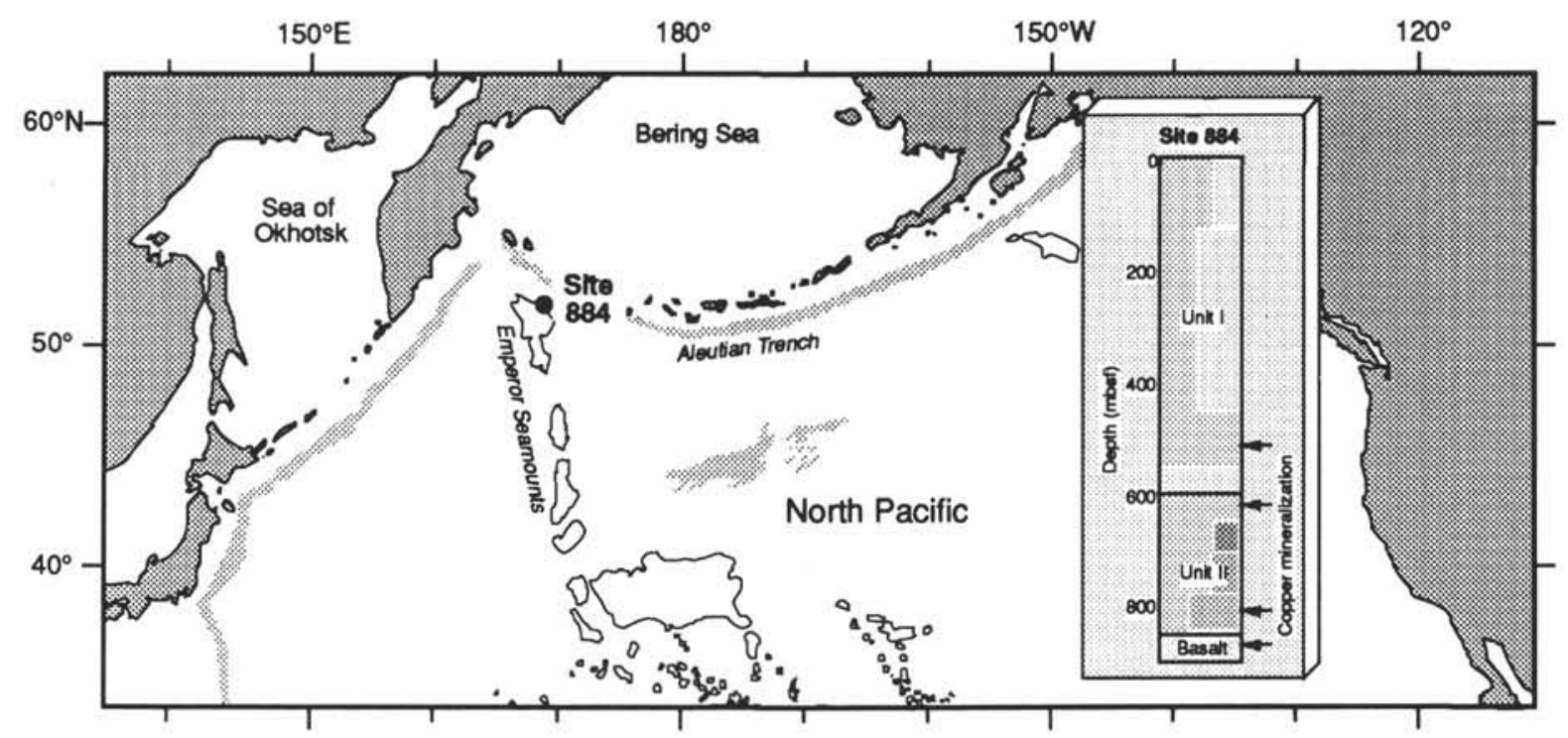

Figure 1. Map showing location of Site 884 in the western North Pacific. The inset is a highly schematic representation of the sedimentary column at Site 884 that indicates depths of copper mineralization. More thorough descriptions of downcore sediment composition are presented in Site 884 core barrel sheets (Rea, Basov, Janecek, Palmer-Julson, et al., 1993).

is noteworthy that blue-green haloes and stringers were observed upon opening the core liners; therefore, these are not an alteration product that formed after prolonged exposure of copper-mineralized sediment to the atmosphere. Also, the base of lithologic Unit I and the entirety of lithologic Unit II (i.e., the sediment that hosts the copper mineralization) clearly have experienced significant reworking and mass movement (as evidenced by scour structures, healed fractures, microfaults, and recumbent folds; Rea, Basov, Janecek, Palmer-Julson, et al., 1993).

\section{PROCEDURES}

This study examined samples from the uppermost interval of copper mineralization (515-521 mbsf). Several bulk samples with copper mineralization were gravitationally settled, decanted, and washed on ship to obtain a clean isolate of copper-colored grains. Mineralogical analyses of these grains were done using shipboard X-ray diffraction (XRD) equipment, and the morphology of the extracted grains was observed subsequently (on shore) with a scanning electron microscope (SEM).

A second set of analyses was performed at The University of Michigan; these involved in situ slices of sediment ("double-bagged" on ship to prevent evaporation of pore water) that contained apparent copper mineralization. Bulk samples were split along regions of copper mineralization with a clean razor, and the sliced samples then were placed under a microscope to observe possible coloration and/or textural features not apparent without visual aid. Most sliced samples were attached then to carbon wafers, coated with carbon, and placed under a Hitachi S-570 SEM equipped with back-scattered electron (BSE) imaging and Kevex energy-dispersive spectroscopy (EDS) systems. The purpose of this latter step was to examine potential textural and chemical changes between copper minerals and the surrounding sediment. Last, several sliced samples that included apparent native copper grains as well as surrounding blue-green haloes (without carbon coating) were ground with mortar and pestle, fixed to glass slides with acetone, and analyzed by XRD on a Philips 3100 $\mathrm{X}$-ray generator.

We suggest (with hindsight) that future studies of deep-sea, sediment-hosted copper should attempt analyses of in situ sediment sam- ples before any separation of copper-colored grains. This recommendation is offered because several important aspects of copper mineralization at Site 884 (e.g., associated minerals) are evident only in in situ samples and are lost upon sediment separation, and also because halite crystals that form upon evaporation of pore water begin to coat copper-mineralized samples and obscure textural relations.

\section{RESULTS AND DISCUSSION}

\section{Separated Copper Grains}

The isolated copper-colored grains were positively identified as native copper based upon prominent XRD peaks at $2 \theta=42.88,50.00$, and 73.78 (interplanar spacing, $d=2.10,1.82$, and $1.28 \AA$ ). As observed by SEM, individual grains of native copper typically are platelike and hexagonal in appearance, $30-250 \mu \mathrm{m}$ in diameter, and have distinct edges (Fig. 2A, B). Several grains also have associated euhedral native copper crystals, exhibit holes in their center, and/or contain fragments of siliceous tests.

\section{In Situ Copper Grains}

Examination of the copper-colored grains in situ revealed that many grains are composed of clusters of small $(<10 \mu \mathrm{m})$ bright red granular euhedral crystals, rather than aforementioned plates of native copper. Such coloration suggests cuprite $\left(\mathrm{Cu}_{2} \mathrm{O}\right)$, and XRD analyses of ground $1-\mathrm{cm}^{3}$ samples with this material indeed display a prominent cuprite peak $(2 \theta=36.39 ; d=2.47 \AA)$ in addition to distinctive peaks for native copper $(2 \theta=43.31 ; d=2.09 \AA)$ and atacamite (discussed below). In fact, sediment samples in which in situ native copper can be observed under the microscope are rare. This suggests that either (1) a thin veneer of cuprite covers many grains of native copper, or (2) much of what appears to be native copper without the aid of a microscope is actually cuprite.

Where in situ plates of native copper are observed, SEM/BSE/ EDS analyses indicate that they are the foci of a relatively complex morphology. Figure 3 shows several plates of native copper intermingled with "massive" calcium carbonate and surrounded by atacamite. The larger plates of native copper are similar in size and shape (platelike with holes) to those physically isolated from the bulk sedi- 
A

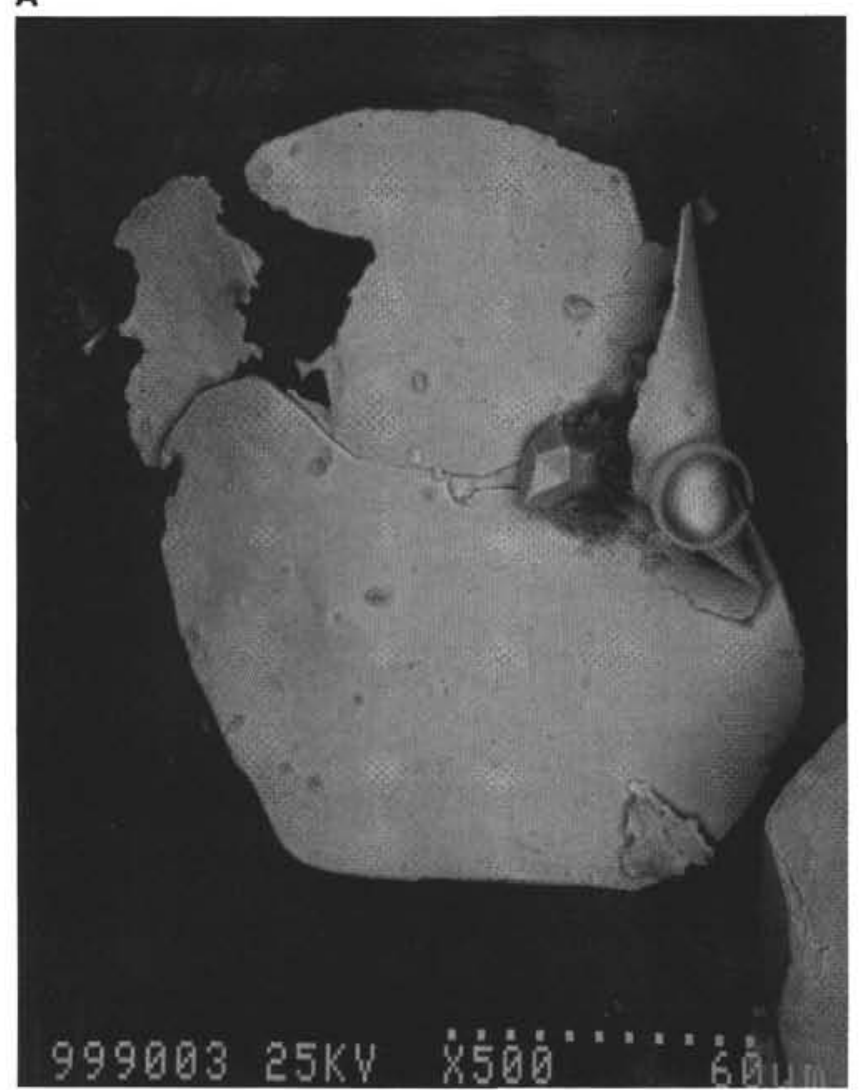

B

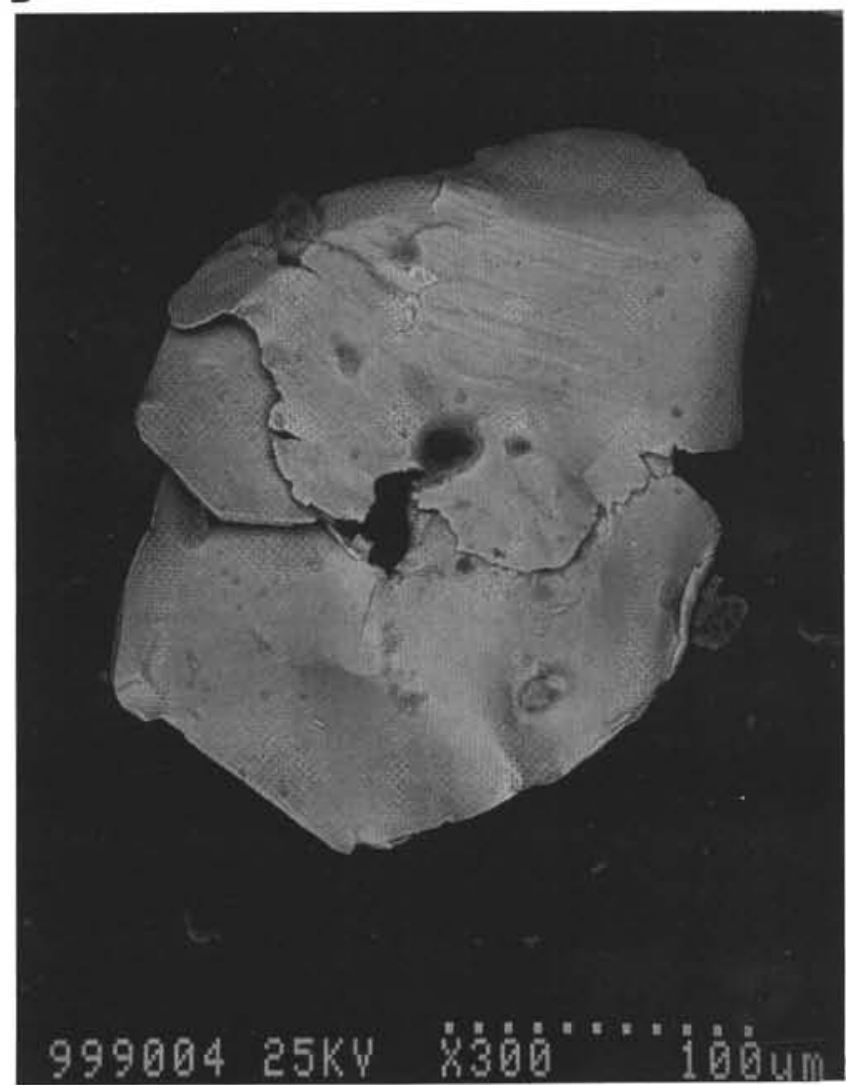

Figure 2. SEM photographs of washed and isolated native copper grains. Such grains typically are platelike in appearance and 30-250 $\mu \mathrm{m}$ in diameter. Isolated native copper grains often contain a hole in their center (filled with clay in Fig. 2A and empty in Fig. 2B). Note sharp edges of grains and the euhedral native copper crystal (Fig. 2A). The circular object in Figure 2A is an incorporated fragment of a siliceous test.

ment. Here, it is apparent that holes within the plates of native copper are filled with calcium carbonate. Although native copper and massive calcium carbonate appear to have been deposited after initial sedimentation, it is not clear in this particular example (Fig. 3) whether carbonate interiors were deposited before, during, and/or after precipitation of native copper.

Analyses of other in situ copper-colored grains clearly indicate that deposition of some of the calcium carbonate preceded copper mineralization. Figure 4 shows a partially dissolved calcareous test inundated with copper mineralization. The mineralogy, size $(\sim 275-$ $\mu \mathrm{m}$ diameter), and chambered structure of the test suggest it is of a foraminifer. In and immediately surrounding the test, native copper and/or cuprite occurs (that native copper and cuprite can be found in the same microsample as discussed above poses a problem for EDS analyses inasmuch as oxygen peaks determined by EDS are small and native copper and cuprite cannot unambiguously be distinguished from one another). Magnesium carbonate also is found within the center of the calcareous test. Figure 5 shows another partially dissolved calcareous test (presumed to be that of a foraminifer) in contact with native copper and/or cuprite and surrounded by atacamite. This figure is particularly enlightening because it demonstrates that atacamite coats both an originally deposited calcareous test as well as previously precipitated native copper and/or cuprite. As exemplified by the three aforementioned figures, copper mineralization invariably is associated with calcium carbonate; in those cases where massive calcium carbonate is lacking, a strong argument also can be made that a substantial portion of the calcium carbonate was deposited before copper mineralization in the form of biogenic tests.

Pyrite and/or copper sulfides were not evident in bulk XRD analyses, nor were they observed during any SEM/EDS analyses. Sediment samples with copper mineralization contain very little nonclay $\mathrm{Fe}$; when such $\mathrm{Fe}$ is found, it exists as small $(<5 \mathrm{~mm})$ oxide and/or oxyhydroxide phases (e.g., Fig. 3A). Metals sometimes associated with copper in terrestrial ore deposits (e.g., $\mathrm{Co}, \mathrm{Pb}$, and $\mathrm{Zn}$ ) also were not observed during SEM/EDS analyses (either within copper minerals or as separate phases).

\section{Stringers and Haloes}

Shipboard descriptions indicate that most "grains of native copper" are surrounded by blue-green haloes. Our microscopic analyses of these haloes indicate they are crystalline and progressively grade into encompassing stark white haloes (also crystalline). Together these haloes can extend up to a centimeter away from the central native copper and/or cuprite core. In most cases, blue-green and white haloes spread along fracture surfaces such that mineralization predominately occurs in two directions. Blue-green stringers appear as tubes under the microscope and often intersect fracture surfaces.

Equilibrium diagrams for copper in seawater at $25^{\circ} \mathrm{C}$ (Bianchi and Longhi, 1973; Rose, 1976, 1989) suggest that at moderate Eh $(>0.3-$ 0.4 volts) and $\mathrm{pH}(\sim 5.5-7.5)$ the most stable phase of copper is the blue-green mineral atacamite $\left(\mathrm{Cu}_{4}[\mathrm{OH}]_{6} \mathrm{Cl}_{2}\right)$, and this mineral previously has been observed in the deep-sea environment near hydrothermal mounds (Alt et al., 1987). Our XRD analyses confirm that blue-green stringers and haloes at Site 884 are composed of atacamite. Bulk samples that contain stringers and haloes display the prominent XRD peak for atacamite $(2 \theta=16.21 ; d=5.47 \AA)$, and discrete microsamples of stringers and haloes show EDS elemental peaks for $\mathrm{Cu}$ and $\mathrm{Cl}$. Diatom fragments often are enmeshed in atacamite haloes and stringers (Fig. 6) where no native copper and/or cuprite is found (i.e., $>1 \mathrm{~cm}$ from copper-colored "grains"). This 


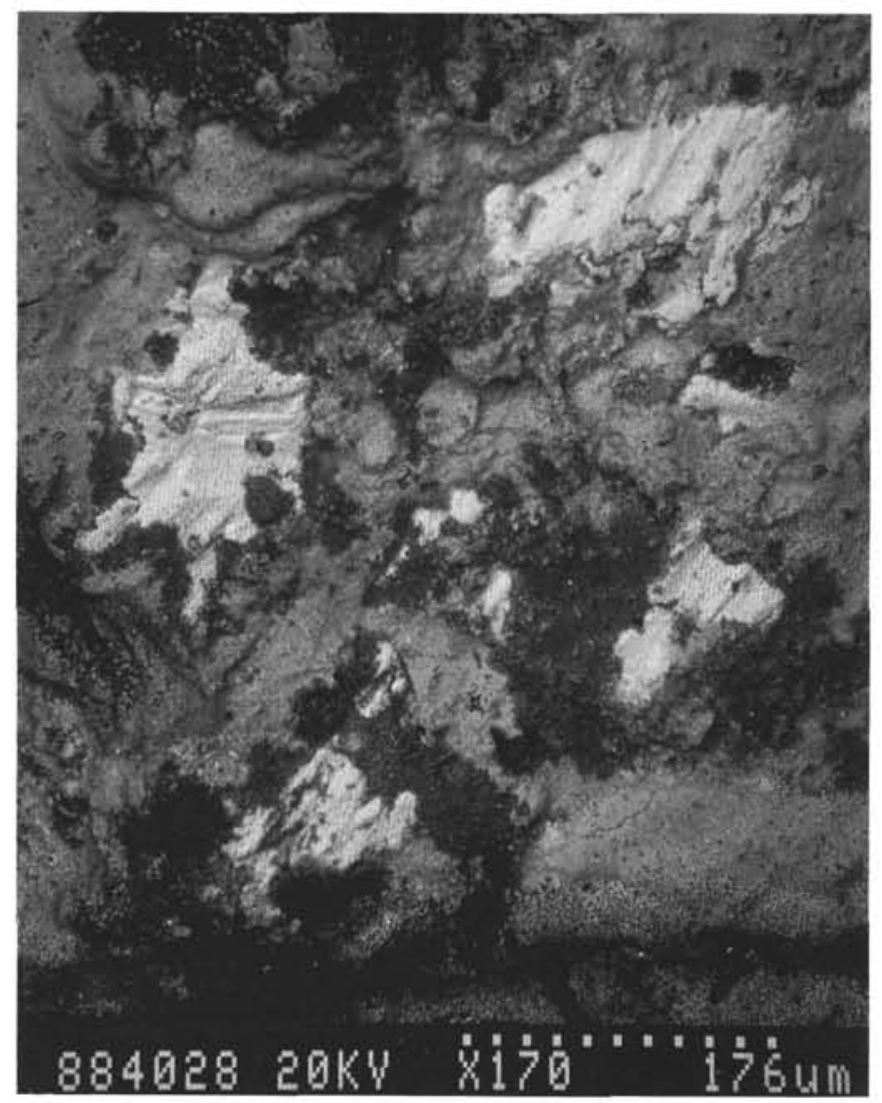

Figure 3. BSE photograph of an in situ sample of copper mineralization along a sediment fracture surface. Relatively large white plates are native copper. The surrounding black and gray matrix is composed of calcium carbonate and atacamite, respectively. The black to gray cores (infilled holes) in native copper plates are composed of calcium carbonate. Small $(<5 \mu \mathrm{m})$ bright white dots speckled throughout the photograph are iron oxyhydroxides (upper left) or barite. No sulfides ( $\mathrm{Cu}$ and/or $\mathrm{Fe}$ ) are present within this or any other investigated sample.

markedly contrasts with calcareous tests: fragments of biogenic carbonate are not seen within atacamite stringers and/or haloes unless intertexturally associated with native copper and/or cuprite. Calcareous tests without adjacent native copper and/or cuprite can be found, however, in sediment that occurs farther away $(\sim 3 \mathrm{~cm})$ from atacamite stringers and/or haloes.

Small $(<5 \mu \mathrm{m})$ euhedral barite crystals are scattered throughout atacamite stringers and haloes (Fig. 6). Because such barite is a ubiquitous minor constituent of pelagic sediment (e.g., Dehairs et al., 1980), and because it occurs in nonmineralized sediment approximately $3 \mathrm{~cm}$ away from copper and associated haloes, we assume that the barite crystals are unrelated to copper mineralization.

The outermost stark white haloes are composed of both calcium carbonate and halite (Fig. 7). The calcium carbonate often occurs as small $(\sim 10 \mu \mathrm{m})$ euhedral rhombs and appears to be an integral element of the copper mineralization phenomena. The halite also may occur as euhedral crystals, and undoubtedly represents evaporation of pore water (SEM photographs of the same samples taken 2 months apart clearly show that halite crystals are growing). Whether the halite has any significance in terms of copper mineralization is difficult to ascertain without further analyses (e.g., bulk sediment $\mathrm{Cl}$ concentrations): abundant halite may reflect evaporation of pore waters with unusually high $\mathrm{Cl}$ (and/or $\mathrm{Na}$ ) concentrations (i.e., a brine), or, simply, evaporation of seawater. We note, however, that halite crystals preferentially form within and around regions of copper mineralization.

\section{Copper Mineralization}

The observations discussed above permit several generalizations regarding copper mineralization at Site 884 . Each case of copper mineralization at Site 884 (i.e., "copper-colored grains") involves a fivefold zonation that resembles a "bullseye" (Fig. 8A, B). There exists (1) a central calcium carbonate core, which respectively is surrounded by rings of (2) native copper and/or cuprite, (3) massive calcium carbonate, (4) atacamite, and (5) calcium carbonate rhombs and halite. This zonation also reflects the order of precipitation (e.g., Fig. 5B). Zone 3 (massive calcium carbonate) is observed only in regions with extensive copper mineralization and little (if any) evidence for preexisting carbonate (i.e., Zone 1). Except for atacamite stringers, copper mineralization exists in planar space (i.e., along sediment fracture surfaces). Textural relations (e.g., copper around foraminifer tests, and atacamite covering diatom fragments) indicate that native copper and cuprite mineralization occurred in situ, after deposition of surrounding sediment, and was inextricably associated with preexisting biogenic calcium carbonate. Carbonate tests cannot be found in mineralized regions without adjacent native copper and/ or cuprite, and native copper and/or cuprite often rims obvious examples of biogenic carbonate.

\section{Depositional Constraints and Possible Mechanisms of Copper Mineralization}

Any depositional mechanism invoked for copper mineralization at Site 884 must be consistent with the above observations and, because such metallogenesis occurred after sediment deposition, it also must explain the precipitation of copper during and/or after the middle Miocene in an open-ocean, deep-water environment. Sediment between 515 and 521 mbsf was deposited between approximately 10.8 and $11.4 \mathrm{Ma}$ (Rea, Basov, Janecek, Palmer-Julson, et al., 1993), and from this time to the present, the top of the sediment column lay between 3800 and $4000 \mathrm{~m}$ below sea level (Leg 145 Shipboard Scientific Party, 1993). We discuss other constraints and possible depositional mechanisms concerning copper mineralization at Site 884 in the following paragraphs.

The preferential occurrence of copper mineralization along fracture surfaces suggests that copper-bearing fluids migrated through surrounding sediment and were derived from an external source. Random distribution of copper minerals within the sediment would be expected if copper mineralization somehow involved local remobilization and reprecipitation of copper. The abundance of copper also argues for an external source of copper inasmuch as total copper (including that hosted within cuprite and atacamite) appears to be far greater than the amount of copper that potentially could be remobilized from immediately surrounding sediment. Deep-sea clays typically contain about 100-200 ppm copper (e.g., Chester, 1990). However, homogenized $5-\mathrm{cm}^{3}$ samples containing copper mineralization phenomena at Site 884 may have upward of $1 \mathrm{wt} \%$ copper (although, to preserve the textural integrity of samples, bulk copper concentrations have not yet been determined).

We suggest that fluids involved in copper deposition at Site 884 (at least in the uppermost mineralized interval 515-521 mbsf) were probably at low temperature $\left(<100^{\circ} \mathrm{C}\right)$, although high-temperature solutions cannot be ruled out with current data. This inference is made because no proximal sources of high-temperature solution exist. Underlying flows of basaltic lava, although relatively close $(\sim 335 \mathrm{~m})$, are not considered as a potential source of high-temperature fluids as they were emplaced at least $40 \mathrm{~m}$.y. before the copper mineralization. The generally small size $(<1 \mathrm{~cm})$ of probable solution conduits (i.e., microfaults and slickenslides) also would facilitate temperature equilibrium with surrounding sediment pore water and likely preclude significant movement of high-temperature solutions. Present porewater temperatures at Site 884 increase downward from $7^{\circ}-9^{\circ} \mathrm{C}$ ( $515 \mathrm{mbsf})$ to $11^{\circ}-13^{\circ} \mathrm{C}$ ( $800 \mathrm{mbsf}$; Rea, Basov, Janecek, PalmerJulson, et al., 1993). 
A

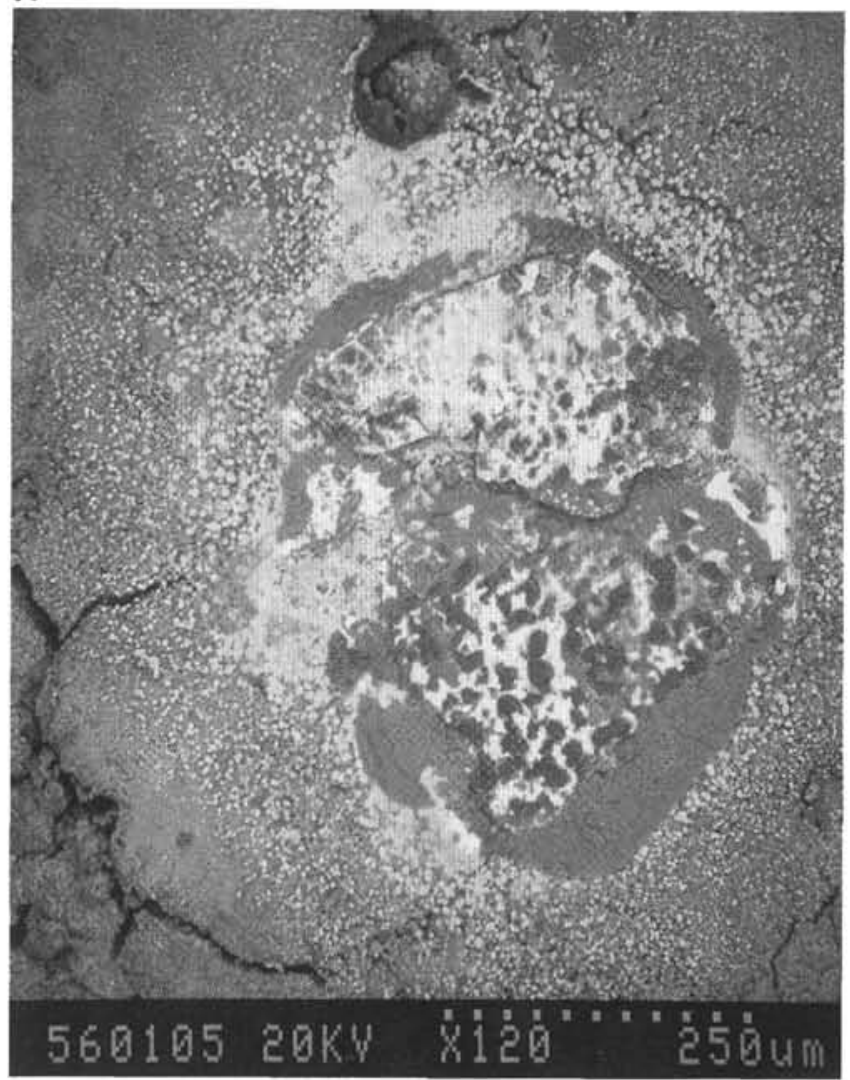

B

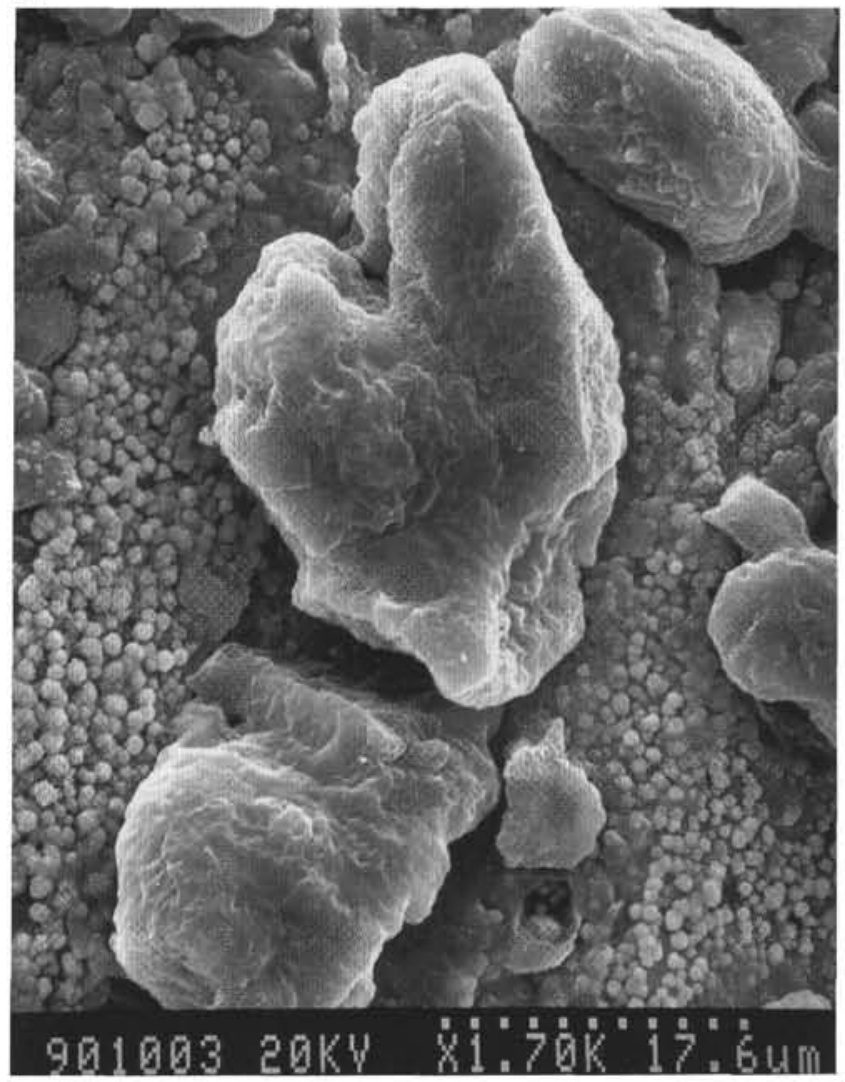

Figure 4. A. BSE image of an apparent "copper-colored grain" hosted on a sediment fracture surface. The grain is better described as a calcareous test inundated with copper mineralization. Dark gray "figure 8 " is the partially dissolved remains of a calcium carbonate test. The size ( $275 \mu$ m diameter) and chambered structure of the test suggest that it is of a foraminifer. Central bright areas are native copper and/or cuprite. Surrounding light gray shades (throughout photograph) are atacamite. B. Close-up SEM photograph of lower chamber. Relatively large grains (black grains in Fig. 4A; $\sim 10-15 \mu \mathrm{m}$ across) are magnesium carbonate. Small euhedral crystals are cuprite and/or native copper.

Excluding extremely carbonated $\left(\mathrm{pCO}_{2}>1 \mathrm{~atm}\right)$ aqueous environments, thermodynamic information indicates that the only viable means of transporting high concentrations of dissolved copper within low-temperature solutions is at relatively high dissolved chloride concentrations $\left(\mathrm{Cl}^{-}>10 \mathrm{mM}\right)$, moderate $\mathrm{Eh}(\sim 0-0.4 \mathrm{~V})$, and moderate to low $\mathrm{pH}(<8.0 ;$ Rose, 1976, 1989). We suggest that copper mineralization at Site 884 was derived from such a fluid. High chloride concentrations undoubtedly existed in solution because metallogenesis occurred in a deep-sea marine environment $\left(\mathrm{Cl}^{-}\right.$in pore water at Site 884 ranges between 554 and $565 \mathrm{mM}$; Rea, Basov, Janecek, Palmer-Julson, et al., 1993). Assuming that copper-bearing fluids also contained relatively high total sulfur concentrations (again because of a deep-sea marine environment), moderate to high Eh might be inferred from the conspicuous absence of iron (and/or copper) sulfides, and the presence of Fe oxyhydroxides and euhedral (preexisting) barite crystals within copper mineralized zones. If copper-bearing solutions were at low Eh (and moderate to low $\mathrm{pH}$ ), precipitation of Fe-sulfides (e.g., pyrite) and dissolution of precursor barite (and $\mathrm{Fe}$ oxyhydroxides) would be expected. The intimate relationship between copper deposition and biogenic calcium carbonate also suggests copper precipitation involved fluids that were more acidic than present-day pore waters. An increase in $\mathrm{pH}$ upon contact with carbonate would account for preferential cuprite precipitation around partially dissolved carbonate tests (see below).

The question of how precipitation of various copper minerals was induced is relevant to economic geology because depositional models concerning terrestrial "red-bed" copper ores (e.g., Rose, 1976, 1989) involve analogous fluids and similar depositional environments (i.e., oxidized claystones and solution conduits), as suggested here for Site 884. Two plausible (and relatively simple) precipitation mechanisms are discussed below. Discrimination between these mechanisms depends on whether cuprite and/or atacamite are regarded as primary minerals or diagenetic products of previously deposited copper minerals. Temperature variations (except for atacamite) are not considered in either case, because changes in temperature (between $25^{\circ}$ and $100^{\circ} \mathrm{C}$ ) do not appear to affect significantly solubility of various copper phases (except that of atacamite; Rose, 1989). We also note that more complicated depositional mechanisms involving successive movements of copper-bearing fluids and multiple stages of copper mineralization are possible.

In the first depositional hypothesis (Fig. 9A), we assume that the suite of copper minerals (native copper, cuprite, and atacamite) represents progressive deposition from a single migrating copperbearing fluid. When the slightly acidic solution contacts a previously deposited (and relatively rare) carbonate test, the carbonate is partially dissolved, and an increase in pH occurs (Eq. 1):

$$
\begin{gathered}
2 \mathrm{CuCl}_{3}^{2-}+\mathrm{H}_{2} \mathrm{O}+3 \mathrm{CaCO}_{3}(\mathrm{~s})+\mathrm{H}^{+} \rightarrow \mathrm{Cu}_{2} \mathrm{O}(\mathrm{s}) \\
+6 \mathrm{Cl}+3 \mathrm{Ca}^{2+}+3 \mathrm{HCO}_{3}^{-},
\end{gathered}
$$

such that cuprite may be precipitated. If precursor carbonate phases contain trace amounts of organic matter, then native copper deposition also may be induced (Eq. 2):

$$
\begin{gathered}
4 \mathrm{CuCl}_{3}^{2-}+2 \mathrm{H}_{2} \mathrm{O}+\mathrm{CH}_{2} \mathrm{O}(\mathrm{s}) \rightarrow 4 \mathrm{Cu}^{2}(\mathrm{~s})+12 \mathrm{Cl}^{-}+ \\
\mathrm{HCO}_{3}^{-}+5 \mathrm{H}^{+} .
\end{gathered}
$$


A

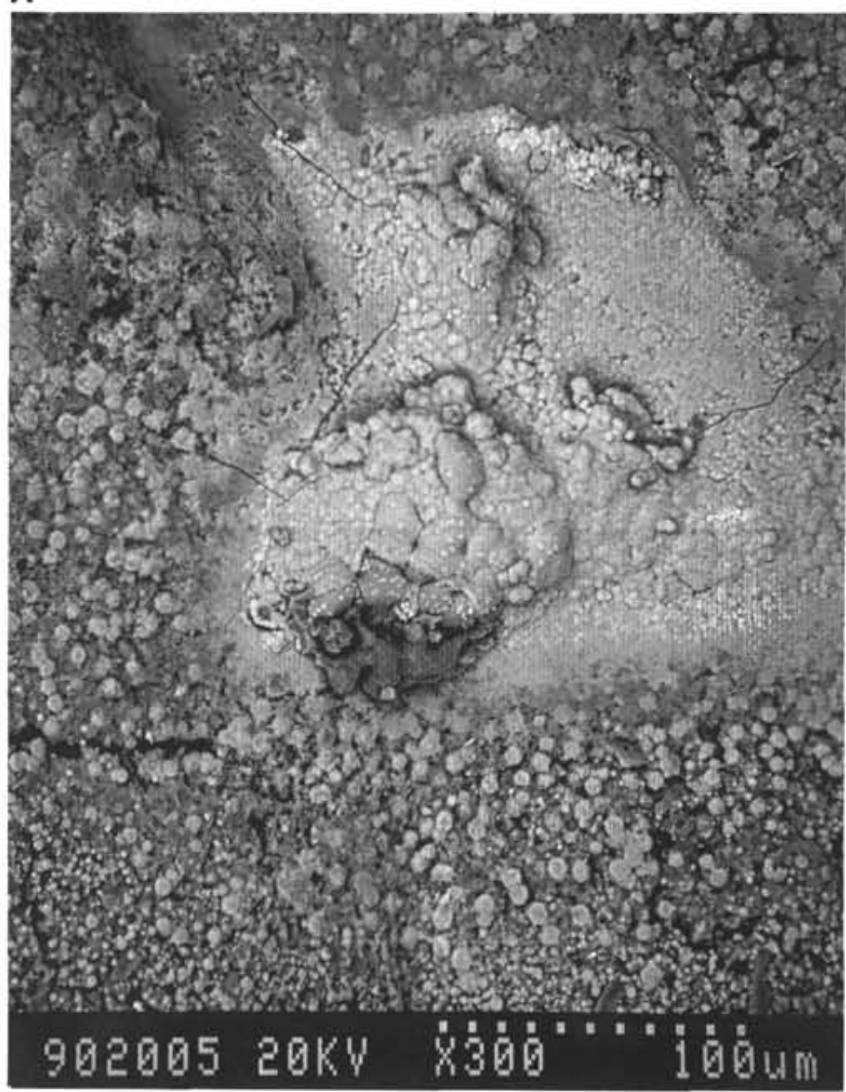

B

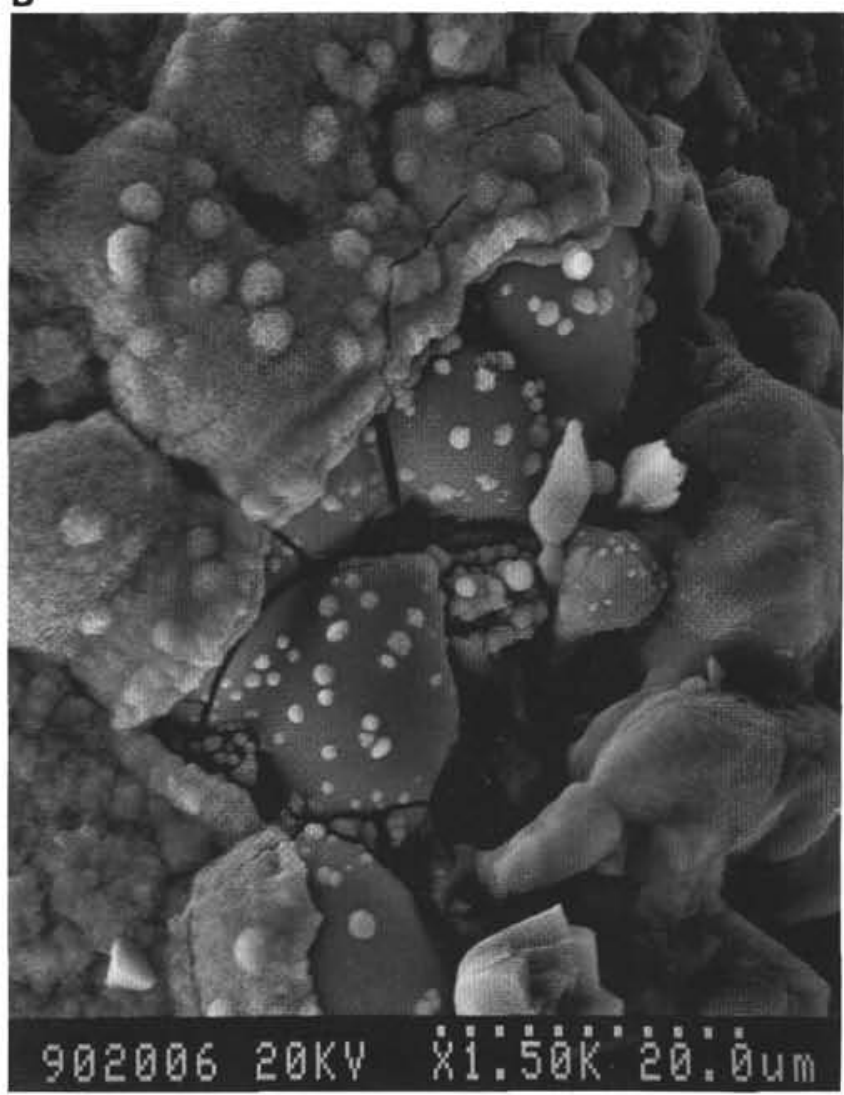

Figure 5. BSE images of a "copper-colored grain" along a sediment fracture surface (the dark central portion of Fig. 5A is shown close-up in Fig. 5B). Analyses again demonstrate that the grain is a partially dissolved calcareous test surrounded by copper mineralization. The test (dark gray) is spherical and approximately $100 \mu \mathrm{m}$ across (foraminifer). However, only a small portion of the test can be observed directly because of a coating of native copper and/or cuprite (white) and atacamite (light gray). Note that atacamite (Fig. 5B) appears to drape over both the calcareous test and preexisting crystals of native copper and/or cuprite.

Models concerning terrestrial sediment-hosted copper deposits have suggested that replacement of preexisting iron sulfides may be an alternative (and predominant) process for initiating the necessary drop in Eh to precipitate native copper (e.g., Brown, 1981; Kirkham, 1989). Although such a reaction cannot be dismissed at Site 884, the lack of pyrite (or for that matter, significant amounts of any reactive iron) throughout the sediment argues against this process. Dissolved calcium and bicarbonate released in the above reactions could then reprecipitate as surrounding massive carbonate and/or carbonate rhombs. Thermodynamic considerations suggest that a copper-chloride solution at the assumed moderate $\mathrm{Eh}$ and $\mathrm{pH}$ will precipitate atacamite upon an increase in Eh, a decrease in temperature, and/or an increase in chloride concentration (Rose, 1989). Subsequent equilibration of the initial copper-bearing fluid with surrounding pore water (assuming the metalliferous solution had higher T, lower Eh, and/or lower $\mathrm{Cl}^{-}$) could therefore explain the abundant atacamite (Eq. 3):

$$
4 \mathrm{CuCl}_{3}{ }^{2-}+6 \mathrm{H}_{2} \mathrm{O} \rightarrow \mathrm{Cu}_{4}(\mathrm{OH})_{6} \mathrm{Cl}_{2}(\mathrm{~s})+10 \mathrm{Cl}^{-}+4 \mathrm{e}^{-}+6 \mathrm{H}^{+} .
$$

Within the context of this mechanism, veins of native copper (and/or cuprite) might reflect movement of copper-bearing fluids along preexisting "veins" of biogenic carbonate. Shipboard lithologic descriptions (i.e., core barrel sheets) indeed indicate that small $(<1$ $\mathrm{mm}$ ) white veins infilled with nannofossils (without copper mineralization) cut across beds in Unit II sediment at Site 884 (Rea, Basov, Janecek, Palmer-Julson, et al., 1993).

Literature in economic geology typically regards atacamite and cuprite as oxidation products of more reduced copper phases (including in the deep-sea environment; Alt et al., 1987); that is, they generally are not thought of as primary precipitates. Consequently, the second proposed depositional mechanism (Fig. 9B) assumes that cuprite and atacamite represent alteration of preexisting native copper and/or possibly chalcocite $\left(\mathrm{Cu}_{2} \mathrm{~S}\right)$, Copper-bearing fluids precipitated chalcocite and/or native copper as veins throughout certain intervals of sediment at Site 884 . These veins subsequently were exposed to oxidized and chloride-rich pore water such that they were altered to cuprite, and ultimately, atacamite (Eqs. 4-6):

$$
\begin{gathered}
\mathrm{Cu}_{2} \mathrm{~S}(\mathrm{~s})+4 \mathrm{H}_{2} \mathrm{O} \rightarrow 2 \mathrm{Cu}(\mathrm{s})+\mathrm{SO}_{4}^{2-}+6 \mathrm{e}^{-}+8 \mathrm{H}^{+}, \\
2 \mathrm{Cu}(\mathrm{s})+\mathrm{H}_{2} \mathrm{O} \rightarrow \mathrm{Cu}_{2} \mathrm{O}(\mathrm{s})+2 \mathrm{e}^{-}+2 \mathrm{H}^{+} \text {, and } \\
2 \mathrm{Cu}_{2} \mathrm{O}(\mathrm{s})+4 \mathrm{H}_{2} \mathrm{O}+2 \mathrm{Cl}^{-} \rightarrow \mathrm{Cu}_{4}(\mathrm{OH})_{6} \mathrm{Cl}_{2}(\mathrm{~s})+4 \mathrm{e}^{-}+2 \mathrm{H}^{+} .
\end{gathered}
$$

Atacamite stringers and haloes, cuprite, and native copper therefore would respectively represent completely oxidized veins of precursor native copper and/or chalcocite, oxidized coatings around native copper, and the interior of originally deposited veins. Chalcocite (if ever present) now has been oxidized completely. A kinetic control of carbonate that abates copper oxidation might explain the association between native copper and/or cuprite and biogenic carbonate. This second model is problematic, however, because it is unclear whether the reductants (i.e., organic carbon and/or pyrite) necessary to precipitate extensive native copper and/or chalcocite veins were abundant within Miocene sediment at Site 884 . Hence, although this proposed depositional mechanism agrees with conventional thinking concerning the presence of cuprite and atacamite, it appears less appealing than the former hypothesis. It is noted that a model combining aspects of both depositional hypotheses also may be used to explain copper mineralization at Site 884 . 


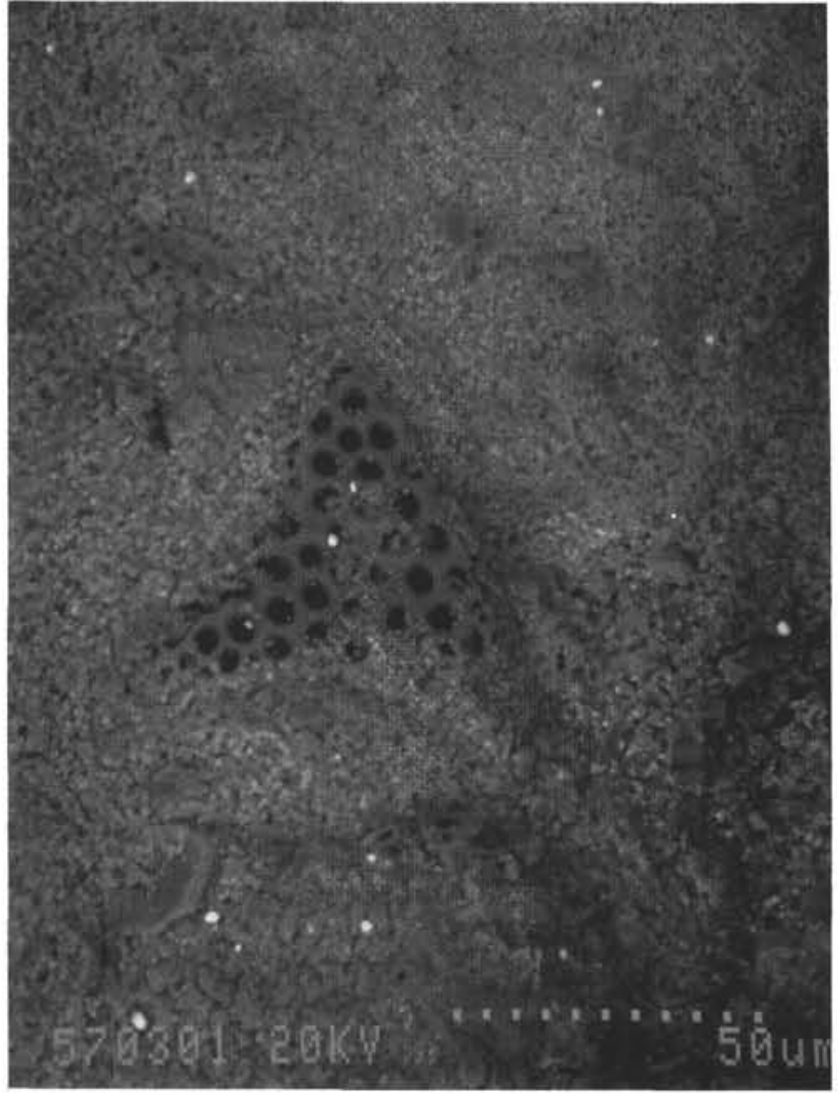

Figure 6. BSE image of a blue-green stringer showing a fragment of a diatom (dark gray object with holes, $\sim 30 \mu \mathrm{m}$ across) enmeshed in atacamite (light gray matrix). Small $(<5 \mu \mathrm{m})$ white spots scattered throughout the photograph are euhedral barite crystals.

Largely open issues include the cause for fluid migration, the source of copper for mineralization, and the lack of metals other than copper. The movement of copper-bearing solutions most likely occurred during and/or after fracturing of sediment. It is possible that pressurized (and possibly warmer) solutions were released during an interval of Miocene tectonism.

Sources of copper commonly proposed for terrestrial examples of sediment-hosted copper include (e.g., Brown, 1981; Kirkham, 1989) (1) oxyhydroxides and clays in the sediment column; (2) organic matter, or (3) basaltic lava flows. Any of these sources is plausible at Site 884 , and we cannot discriminate between them with the available information. Two observations are noteworthy, however, inasmuch as they make the latter source of copper appear feasible. The entire sedimentary sequence beneath the observed copper mineralization contains numerous fracture surfaces (i.e., potential conduits to basalt), and native copper occurs (as a vein) in the underlying basaltic lava flows. That copper mineralization is found in specific intervals of the sedimentary column cannot be used as an argument against an underlying basaltic source of copper. This merely may indicate that copper-bearing solutions were migrating upward from basalt, but only along certain fracture surfaces that were diagonal to drilling.

Because metals other than copper (e.g., $\mathrm{Co}, \mathrm{Pb}$, and $\mathrm{Zn}$ ) also are relatively soluble at the assumed fluid conditions (i.e., low temperature, moderate Eh, moderate $\mathrm{pH}$, and seawater anion concentrations), and because these same metals may precipitate (as carbonates and/or sulfides) upon the inferred changes in $\mathrm{Eh}$ and $\mathrm{pH}$, the absence of these metals in copper-mineralized sediment at Site 884 is somewhat intriguing. The original fluid that leached copper (from whatever source) may not have obtained these other metals. Alternatively, Rose (1989) has suggested the lack of these metals in certain "red-bed" copper ores

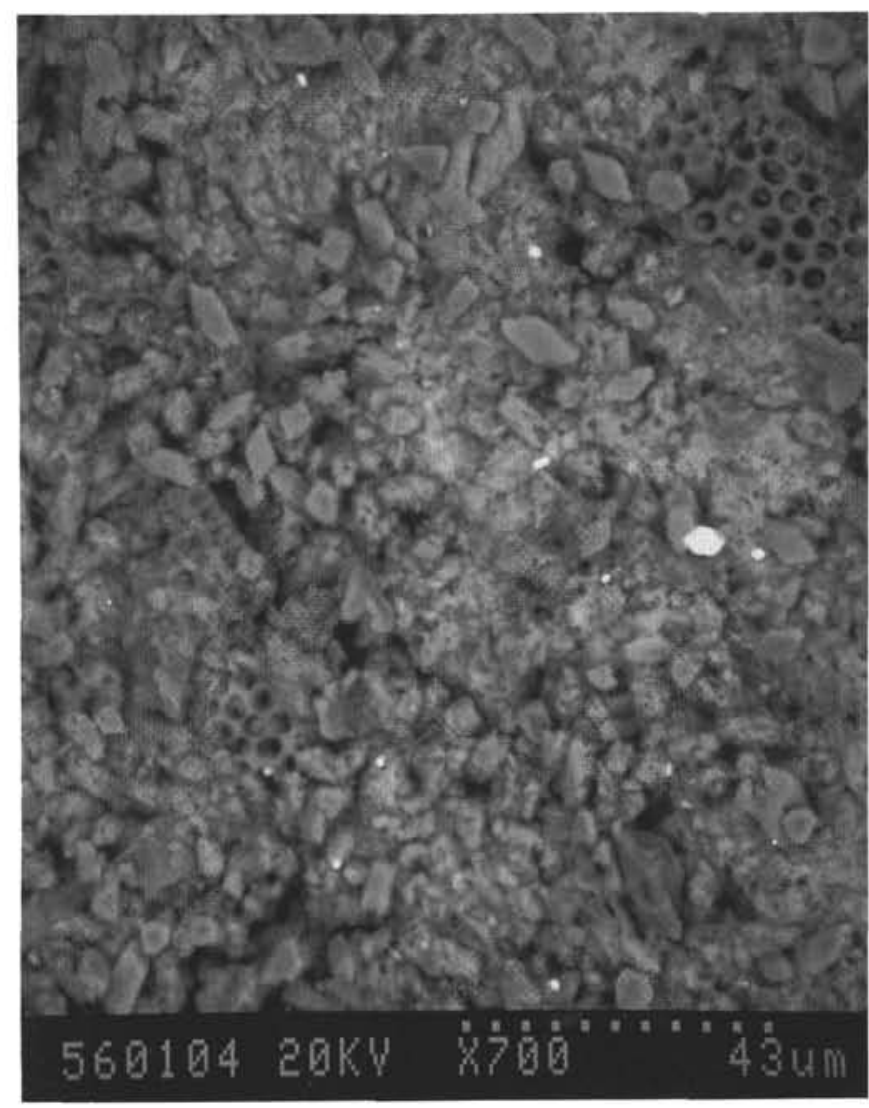

Figure 7. BSE image of a stark white halo showing fragments of diatoms, numerous small (5-10 $\mu \mathrm{m})$ calcium carbonate rhombs (light gray), and several barite crystals (bright white) surrounded by a predominantly halite (light gray) matrix.

results because copper as $\mathrm{CuCl}_{3}^{2-}$ is not as strongly adsorbed onto iron oxyhydroxides as $\mathrm{Co}, \mathrm{Pb}$, and $\mathrm{Zn}$ and is therefore separated from these metals during fluid transport through oxidized sediment.

\section{Comparison to Other Occurrences of Pelagic Copper}

Before drilling at Site 884, sediment-hosted native copper had been reported within pelagic sequences at five widespread DSDP sites (Zemmels et al., 1972; Donnelly and Nalli, 1973; Jenkyns, 1976; Siesser, 1978; Knox, 1985): 105 (northwest Atlantic), 149 (Caribbean Sea), 317 (central Pacific), 364 (east central Atlantic), and 550 (northeast Atlantic). Although descriptions are limited, several similarities exist between copper mineralization at these DSDP sites and at Site 884 .

The most basic similarity is that copper mineralization at all six locations clearly was deposited both in situ and after deposition of surrounding sediment. Perhaps the most striking example is at Site 364, where native copper infills foraminifer tests (Siesser, 1978). A relatively simple mineralogical assemblage also is described at each location. Blue-green coatings (although without mineralogical analyses) were reported to surround native copper at Sites 105, 317, 364, and 550 (Zemmels et al., 1972; Jenkyns, 1976; Siesser, 1978; Knox, 1985). Notably absent, however, were descriptions of copper sulfides, other metal (e.g., $\mathrm{Co}, \mathrm{Pb}$, and $\mathrm{Zn}$ ) phases, and, with the exception of Site 149 (Donnelly and Nalli, 1973), pyrite. In addition, native copper occurs in association with previously deposited carbonate at all six sites. Native copper is found in and/or adjacent to foraminifer and/or nannofossil tests at Sites 149, 364, and 550 (Donnelly and Nalli, 1973; Siesser, 1978; Knox, 1985), and with limestone layers at Site 317 (Jenkyns, 1976). Although native copper is not found with calcium carbonate at Site 105 , it occurs with magnesium carbonate, 


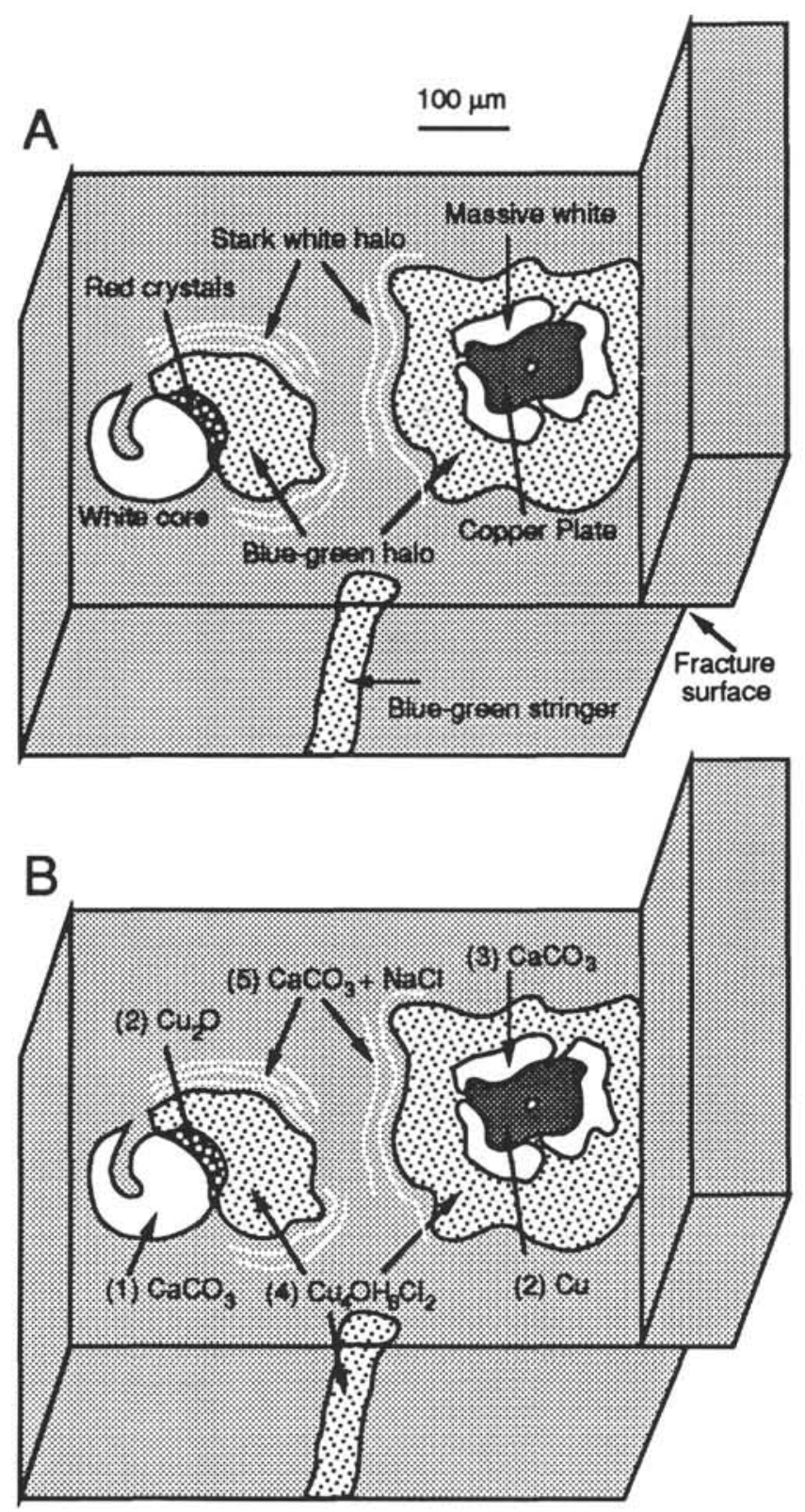

Figure 8. Copper mineralization at Site 884 summarized in terms of (A) color and texture relations, and (B) mineralogical composition and order of deposition. Copper mineralization predominantly occurs along fracture surfaces (except blue-green stringers) and involves fivefold zonation. There is (1) a core of white calcium carbonate that progressively is surrounded by (2) native copper and/or red crystals of cuprite, (3) massive white calcium carbonate, (4) blue-green atacamite, and (5) white calcium carbonate rhombs and halite. This order of zonation also is the order of precipitation. Note that massive calcium carbonate (Zone 3 ) only is apparent when the central calcium carbonate core (Zone 1) cannot readily be identified as a biogenic test. Blue-green stringers are composed of atacamite and may crosscut fracture surfaces.

and Zemmels et al. (1972) have speculated that this may reflect replacement of precursor calcium carbonate during copper emplacement. Abundant evidence for folding and slumping also was noted at Sites 105 and 317 (Hollister, Ewing, et al., 1972; Schlanger, Jackson, et al., 1976).

Attributing pelagic sediment-hosted copper phenomena to movement of chloride-rich, moderate Eh and $\mathrm{pH}$ solutions along preexisting conduits was previously postulated only at Site 317 (Jenkyns,
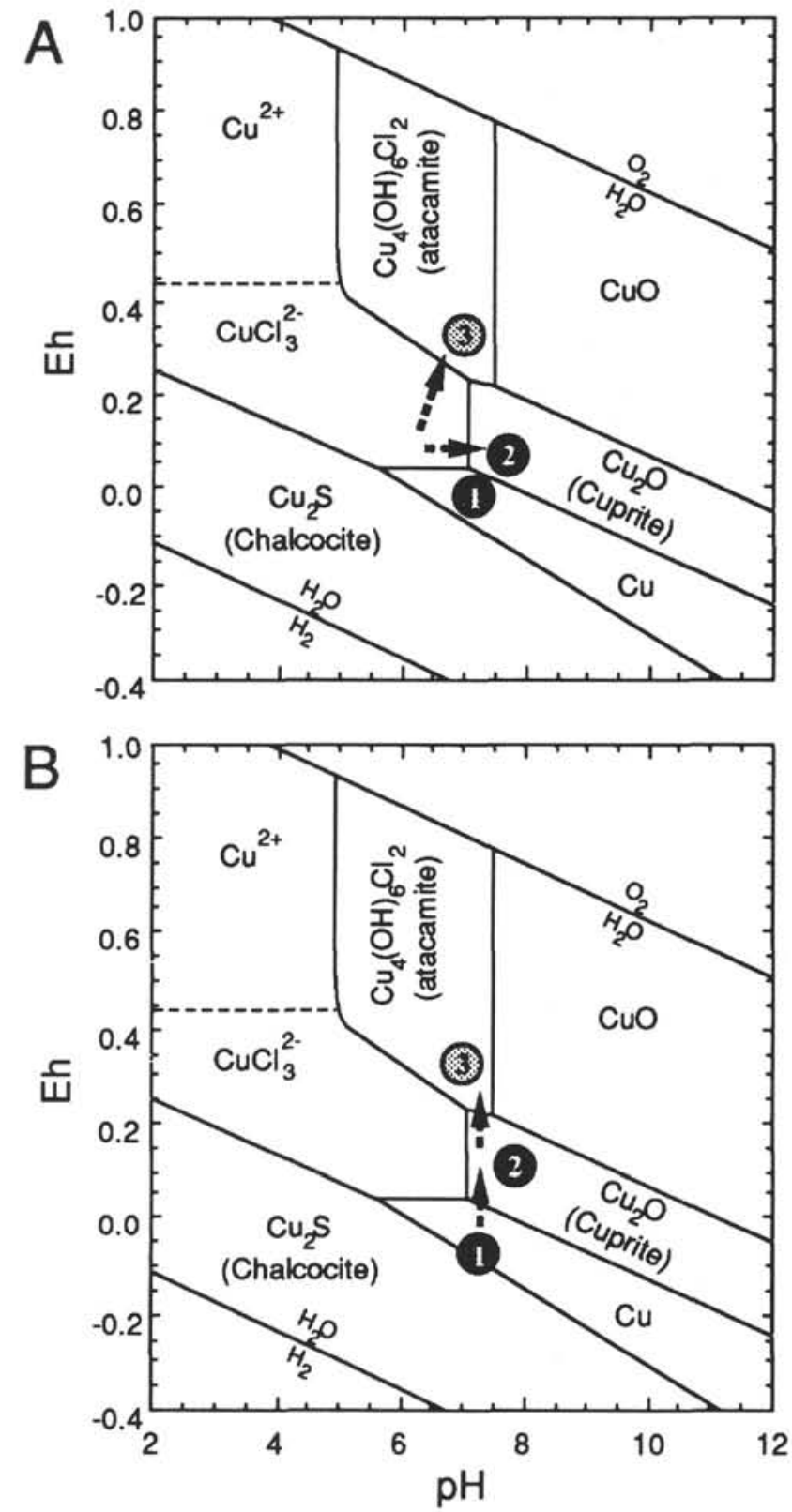

Figure 9. Possible depositional hypotheses for copper mineralization at Site 884 displayed on Eh-pH diagrams for the Cu-Cl-H-O-S system. Hypothesis 1 (A): copper chloride solutions precipitated native copper and/or cuprite upon contact with calcareous tests. The increase in $\mathrm{pH}$ could occur with dissolution of carbonate, and the drop in Eh could reflect oxidation of organic matter in the tests. A subsequent increase in solution Eh, a decrease in temperature, and/ or an increase in chloride concentration caused atacamite precipitation. In this model, atacamite stringers and haloes are primary but were formed after native copper and/or cuprite deposition. Hypothesis 2 (B): copper-bearing fluids precipitated native copper (and/or possibly chalcocite) as veins throughout the sediment. As pore waters evolved, these veins oxidized to cuprite and ultimately atacamite. Remaining native copper and cuprite in this scenario would reflect the interior of originally deposited veins. Associated calcium carbonate, therefore, might represent a kinetic control on copper oxidation. Background Eh-pH diagrams for both models were calculated from thermodynamic data in Faure (1991). Temperature is $25^{\circ} \mathrm{C}$, ionic strength is 0.7 , and activities are $0.00025,0.344$, and 0.00336 for $\mathrm{CuCl}_{3}{ }^{2-}, \mathrm{Cl}^{-}$, and $\mathrm{SO}_{4}{ }^{2-}$, respectively. 
1976). Jenkyns (1976) further speculated that copper precipitation at this site was induced by changes in Eh-pH upon fluid contact with previously deposited carbonate. In light of our findings at Site 884, we suggest that proposed depositional mechanisms at other DSDP sites might be reevaluated. There is, however, no a priori reason to suspect a single depositional mechanism that would explain all occurrences of deep-sea, sediment-hosted copper.

\section{SUMMARY}

Copper mineralization was observed in several intervals of the lithologic column at Site 884. In the uppermost interval, this mineralization occurs along fracture surfaces in claystones. Results presented here indicate that copper mineralization can be described as comprising four successive zones (native copper and/or cuprite, calcium carbonate, atacamite, and calcium carbonate) that surround a core of preexisting calcium carbonate. On the basis of such zonation and other lithologic considerations, we suggest the following general depositional mechanism for copper minerals at Site 884: low-temperature, slightly acidic, moderate $\mathrm{Eh}$, and chloride-rich fluids precipitated native copper (and possibly cuprite) during Eh-pH changes upon contact with previously deposited carbonate tests. Atacamite subsequently precipitated as either original metalliferous fluids evolved with time, or native copper and/or cuprite were oxidized.

\section{ACKNOWLEDGMENTS}

Funding for G.R. Dickens was supported by the U.S. Department of Energy under appointment to Graduate Fellowships for Global Change administered by Oak Ridge Institute for Science and Education (ORISE). The scanning electron microscope used in this work was acquired under grant \#BSR-83-14092 from the National Science Foundation. The authors wish to thank S.E. Kesler, J. Graney, and P.A. Knoop for suggestions during discussion of this work, and M.J. Cruickshank, W.G Siesser, and J.F. Allan for helpful comments based on an earlier version of this manuscript. We also thank Charly's for preliminary chemical support.

\section{REFERENCES $*$}

Alt, J.C., Lonsdale, P., Haymon, R., and Muehlenbachs, C., 1987. Hydrothermal sulfide and oxide deposits on seamounts near $21^{\circ} \mathrm{N}$, East Pacific Rise. Geol. Soc. Am. Bull., 98:157-168.

Bianchi, G., and Longhi, P., 1973. Copper in sea-water, potential-pH diagrams. Corros. Sci., 13:853-864.

Brown, A.C., 1981. The timing of mineralization in stratiform copper deposits. In Wolf, K.H. (Ed.), Handbook of Strata-bound and Stratiform Ore Deposits (Vol. 9): Elsevier (Amsterdam), 1-23.
Chester, R., 1990. Marine Geochemistry: London (Unwin Hyman).

Dehairs, F., Chesselet, R., and Jedwab, J., 1980. Discrete suspended particles of barite and the barium cycle in the open ocean. Earth Planet. Sci. Lett., 49:528-550.

Donnelley, T.W., and Nalli, G., 1973. Mineralogy and chemistry of Caribbean sediments. In Edgar, N.T., Saunders, J.B., et al., Init. Repts. DSDP, 15; Washington (U.S. Govt. Printing Office), 929-961.

Faure, G., 1991. Principles and Applications of Inorganic Geochemistry: New York (Macmillan).

Hollister, C.D., Ewing, J.I., et al., 1972. Init. Repts. DSDP, 11: Washington (U.S. Govt. Printing Office).

Jenkyns, H.C., 1976. Sediments and sedimentary history, Manihiki Plateau, South Pacific Ocean. In Schlanger, S.O., Jackson, E.D., et al., Init. Repts. DSDP, 33: Washington (U.S. Govt. Printing Office), 873-890.

Kirkham, R.V., 1989. Distribution, settings, and genesis of sediment-hosted stratiform copper deposits. In Boyle, R.W., Brown, A.C., Jefferson, C.W., Jowett, E.C., and Kirkham, R.V. (Eds.), Sediment-hosted Stratiform Copper Deposits. Geol. Assoc. Canada, Spec. Pap., 36:3-38.

Knox, R.W.O'B., 1985. Note on the occurrence of native copper in Tertiary nannofossil oozes from the Goban Spur (Hole 550). In Graciansky, P.C., Poag, C.W., et al., Init. Repts. DSDP, 80 (Pt. 2): Washington (U.S. Govt. Printing Office), 851-852.

Leg 145 Shipboard Scientific Party, 1993. Paleoceanographic record of North Pacific quantified. Eos, 74:406-411.

Rea, D.K., Basov, I.A., Janecek, T.R., Palmer-Julson, A., et al., 1993. Proc. $O D P$, Init. Repts., 145: College Station, TX (Ocean Drilling Program).

Rose, A.W., 1976. The effect of cuprous chloride complexes in the origin of red-bed copper and related deposits. Econ. Geol., 71:1036-1048.

, 1989. Mobility of copper and other heavy metals in sedimentary environments. In Boyle, R.W., Brown, A.C., Jefferson, C.W., Jowett, E.C., and Kirkham, R.V. (Eds.), Sediment-hosted Stratiform Copper Deposits. Geol. Assoc. Canada, Spec. Pap., 36:97-110.

Schlanger, S.O., Jackson, E.D., et al., 1976. Init. Repts. DSDP, 33: Washington (U.S. Govt. Printing Office).

Siesser, W.G., 1978. Native copper in DSDP Leg 40 sediments. In Bolli, H.M., Ryan, W.B.F., et al., Init. Repts. DSDP, 40 (Suppl., Pt. 3): Washington (U.S. Govt. Printing Office), 761-765.

Zemmels, I., Cook, H.E., and Hathaway, J.C., 1972. X-ray mineralogy studies-Leg XI. In Hollister, C.D., Ewing, J.I., et al., Init. Repts. DSDP, 11: Washington (U.S. Govt. Printing Office), 729-791.

\footnotetext{
- Abbreviations for names of organizations and publications in ODP reference lists follow the style given in Chemical Abstracts Service Source Index (published by American Chemical Society).
}

Date of initial receipt: 4 April 1994

Date of acceptance: 10 August 1994

Ms 145SR-129 